Please do not remove this page

RMIT

UNIVERSITY

\title{
A Framework for Ameliorating Risk in Australian University Crowdfunding
}

O'Donnell, Jonathan

https://researchrepository.rmit.edu.au/esploro/outputs/9921888098301341/filesAndLinks?institution=61RMIT_INST\&index=null

O'Donnell, J. (2020). A Framework for Ameliorating Risk in Australian University Crowdfunding. In Legal Regulations, Implications, and Issues Surrounding Digital Data (pp. 41-67). IGI Global.

https://doi.org/10.4018/978-1-7998-3130-3.ch003

Document Version: Published Version

Published Version: https://doi.org/10.4018/978-1-7998-3130-3.ch003

Repository homepage: https://researchrepository.rmit.edu.au

Copyright (c) 2020, IGI Global. Copying or distributing in print or electronic forms without written permission of IGI Global is prohibited

Downloaded On 2023/04/26 21:30:26 +1000 


\title{
A framework for ameliorating risk in Australian university crowdfunding
}

\author{
Jonathan O'Donnell ${ }^{1}$ \\ RMIT University, Australia
}

\section{INTRODUCTION}

Crowdfunding - raising funds from a group for a project, typically using the internet provides a new method for funding research at universities. This chapter focuses on the crowdfunding activities of academics at Australian universities in the scope of their institutional research commitments. It examines the risks for the individuals, the universities and the public in crowdfunding campaigns in Australia, using an existing framework for managing risk in crowdfunding services (Stack, et al., 2017). Finally, to assist universities to address these risks, it provides a framework for ameliorating risk before, during and after crowdfunding campaigns.

The chapter does not seek to provide advice to academics who are undertaking crowdfunding in a personal capacity, or to provide advice to students or others affiliated with Australian universities. It focuses on crowdfunding as delineated through the employer-employee relationship of universities and their academics.

Restricting the discussion to universities limits the scope of this chapter to donation-based crowdfunding and rewards-based crowdfunding. While there are examples of universities using crowdfunding to raise equity, they are rare. Risks related to equity crowdfunding have been extensively discussed elsewhere (Cui \& Zeng, 2016; Hornuf \& Schwienbacher, 2017). The author has also not examined loan-based crowdfunding undertaken by universities.

The chapter begins by providing an understanding of the funding of research in Australian universities, of crowdfunding in general and of crowdfunding in Australian universities. It examines the literature on academic crowdfunding, risks related to crowdfunding in general and frameworks for understanding those risks. It describes the research undertaken for this chapter, including interviews and archival research. It outlines the difference between crowdfunding campaigns inside and outside of universities. It identifies risks relating to crowdfunding at Australian universities, using Stack's framework of ill-intentioned and wellintentioned actors. It then provides a new framework for ameliorating those risks.

\section{BACKGROUND}

\section{Understanding Research and Crowdfunding}

\footnotetext{
${ }^{1}$ I would like to thank Margaret Jackson and Marta Poblet for their encouragement and advice, Sophie Couchman and two anonymous referees for their helpful feedback, and Hugh McVicker and Chiara Condotta for supporting me during the final editing. None of this work would have been possible without the ongoing support and encouragement of Sophie Couchman. I am also grateful to the Australian government for their support of this research through a part-time Australian Government Research Training Program Scholarship.
} 
To understand how crowdfunding might fund research activities at Australian universities, it is first necessary to understand the research landscape at Australian universities. Research in Australian universities is defined as "creative and systematic work undertaken in order to increase the stock of knowledge - including knowledge of humankind, culture and society and to devise new applications of available knowledge” (Department of Education and Training, 2017, p. 6).

This definition covers all research activities within the university sector. As most of the major art schools in Australia are attached to universities, it includes creative work such as visual art and creative writing when undertaken by university academics. For the purposes of this chapter, it includes activities associated with research, such as scholarly publication and research communication to the general public (also referred to as sci. comm.). It excludes activities related to teaching, except for research into education theory and practice.

Research at Australian universities is funded through a mix of competitive government grants, industry research contracts and philanthropic donations. Generally, an applicant for a grant responds to a call for applications, submits a written application which usually peer assessed, and undergoes a formal competitive selection process. Crowdfunding provides a new model for research funding in the university sector as it differs from other funding models in four ways.

First, it is not competitive. As crowdfunding campaigns are driven by personal networks, they are not necessarily competing against one another for contributions. Second, there is no written contract signed by all parties that specifies timelines, deliverables and outcomes. Third, aside from university policies, there are no rules specifying what work can and cannot be done, and what funds can and cannot be spent on. This means that crowdfunding can be used to fund work that can be difficult to fund otherwise:

- Extension or top-up funding for a grant or contract that does not provide quite enough funding.

- Pilot funding for exploring formative ideas or for background scholarship to develop ideas.

- Writing up and publication funds for completed work.

- Research communication and science communication, either through public awareness campaigns or research communication such as blogging or podcasting.

- Funding projects that have not been funding through a peer-review grant program.

Finally, there is no peer review process at the funding stage. In this, crowdfunding is more similar to industry research funding and a lot of philanthropic funding, which are often not peer reviewed.

Like any other form of research funding, crowdfunding contributions enable academics to do more than they would otherwise have been able to do without the funding.

Crowdfunding via the internet provides an innovative way for people and organizations to mobilize their networks to raise funds for equity, goods and services, loans or public benefit projects (Belleflamme et al., 2013; Cumming et al., 2015). A crowdfunding service provides a gateway or escrow service between those people who seek to raise funds (crowdfunders) and their contributors, who provide funds. The crowdfunding service provides a website 
(crowdfunding platform) which allows the crowdfunders to present their case to the public through a short narrative which presents the benefits of their work (Swords, 2018). Examples of crowdfunding services include Chuffed, FundScience, GetFunding, GoFundMe, Indiegogo, Kickstarter, Patreon, Pozible, Rockethub and Thinkable. While they all operate in slightly different ways, they all provide a way for contributors to provide funds to crowdfunders. Chuffed, Pozible and Thinkable are based in Australia. All the other crowdfunding services in this chapter are based in other countries but allow Australians to undertake crowdfunding. Australian crowdfunders (including academics) are not restricted to using Australian-based crowdfunding services. They can use any crowdfunding service that will transfer funds to an Australian bank account.

The work required for crowdfunding can be divided into three stages:

- Before the campaign: Crowdfunders prepare a narrative that they will present to the public, describing what they want to do. They plan their communication strategy and identify the people and organizations that they will ask for funding. The crowdfunding service may undertake a brief review before the campaign is published, to ensure it meets their terms and conditions.

- During the campaign: Crowdfunders publish their narrative on a crowdfunding platform, which signals the start of their crowdfunding campaign. They then implement their communication strategy to attract supporters. This generally involves reaching out to their personal networks through social media as well as presenting their narrative to broadcast media such as newspapers and talk-back radio. They may need to change strategy during the campaign, if they are not attracting enough contributions.

- After the campaign: If the campaign has been successful, the crowdfunding service will transfer contributions to the nominated bank account. The crowdfunders should spend those contributions as described in the campaign and disperse any rewards, 'thank you' gifts and tax deductibility receipts. There is also a general expectation that crowdfunders will keep supporters informed of their progress.

In a university setting, there may be additional requirements to each of these three stages:

- Before a campaign: If the university has a policy regarding crowdfunding, the crowdfunder may be required to submit the campaign for internal review. A communications or media team may also be able to advise on the communication plan.

- During the campaign: Groups or units within the university may provide support. For example, the communications team may promote the campaign to the media and through social media. The alumni relations team may promote the campaign to alumni. The donor relations team may promote the campaign to potential donors. Parts of the university may also contribute funds to the campaign.

- After the campaign: The funds must be transferred from a general university account to the crowdfunder's project account. The crowdfunder may be required to submit their research plan for ethics approval before beginning their research.

There are four main types of crowdfunding services. The first is donation crowdfunding where crowdfunders are raising funds for a cause or as apublic good. The supporters are not seeking a material return for their funds, although they may receive some sort of 'thank you' gift (such as a coffee cup) or a tax deduction. Academic crowdfunders often fit into this category, as they are raising funds for research as a public good. The crowdfunding campaign funds a research project which does not seek to develop a specific product or service. 
The second type is rewards crowdfunding in which crowdfunders are developing a new product or service. Their crowdfunding campaign is often designed to generate orders (prepurchase) for their product or service. Supporters are funding this development in return for access to the product or service. Academics at Australian universities have raised funds to create art events (with tickets to the event as the reward) and fund publications (with the published book or magazine as the reward). Some independent research projects have used crowdfunding to raise funds for research-based product design, by generating orders for their final product.

The third type is equity crowdfunding in which crowdfunders are raising equity for a profitmaking concern, and supporters are seeking a return on their investment. They gain an equity stake in the project. The fourth type is loan crowdfunding where crowdfunders are seeking a loan, and supporters expect them to pay back that loan, generally with interest.

As mentioned in the Introduction, the scope of this chapter is restricted to crowdfunding for donations and rewards, as universities rarely undertake crowdfunding for equity or loans.

Crowdfunding campaigns collect funds in three distinct ways:

- All-or-nothing: The crowdfunder sets a minimum target that must be reached over a set period of time. Supporters pledge payments during the campaign, which come due at the end of the campaign if the target has been reached. If the target is not reached, the crowdfunder gets nothing. All-or-nothing campaigns are suitable for projects where there are fixed costs, such as product development.

- Flexible funding: The crowdfunder keeps all funds raised, no matter how small. Flexible funding campaigns are suitable for charitable projects, where every dollar can be used to help a cause. They are also known as 'keep-it-all' campaigns.

- Crowd-patronage: The crowdfunder collects regular funding contributions on an ongoing basis. Crowd-patronage campaigns are suitable for supporting on-going episodic work, such as podcasts and YouTube channels.

These types of crowdfunding and ways of collection funds are combined in Table 1.

\begin{tabular}{|l|l|l|c|c|}
\hline & \multicolumn{1}{|c|}{ Donations } & \multicolumn{1}{c|}{ Rewards } & Equity & Loans \\
\cline { 1 - 2 } All-or-nothing & e.g. Pozible & e.g. Kickstarter & \multicolumn{1}{|c}{ Not considered in this chapter } \\
\cline { 1 - 2 } Flexible funding & e.g. Chuffed & & \\
\cline { 1 - 2 } Crowd-patronage & e.g. Patreon & & \\
\hline
\end{tabular}

Table 1: Types of crowdfunding campaigns and funding, showing the scope of this chapter.

Crowdfunding for donations and rewards is a very democratic process. Any individual or group can set up a crowdfunding campaign as long as they meet the terms and conditions of the crowdfunding service. They must meet an age limit (18 years or older to use Australian crowdfunding services) and must hold a bank account in a country that the crowdfunding service is authorized to operate in. Their campaign can be for any purpose that meets the terms and conditions of the crowdfunding service. As such, university academics may conduct campaigns in their personal or their professional capacity. If their campaign has no 
relation to their work, they might represent themselves as an individual, without any mention of their university affiliation. This would be appropriate if their campaign is related to a hobby or a charity that they support. Some will conduct a campaign as a public intellectual. If their campaign is related to their area of expertise, they might highlight their university affiliation and accreditation, but run the campaign outside of their university processes. In this instance, they are acting as a public intellectual, much as they would if they were speaking to the media. This might be appropriate if they were collaborating with academics from multiple universities, or if their university had no process or policy supporting crowdfunding. In this case, funds raised would not be transferred to their university. Finally, academics could undertake their campaign as an academic employed by their university, with funds being transferred to a university bank account. This will only work if their university has processes in place to enable is to happen.

So, an academic may undertake a crowdfunding campaign as an individual, or as the agent of their employer (the university). If they are acting as a public intellectual, it is unclear if they are acting as an employee or as an individual. They are relying on their association with their university, but the funds are not being transferred to a university bank account. This is an important distinction, as it will determine whether the employment contract between the academic and their university applies. It may also create a conflict of interest.

Academics at Australian universities began crowdfunding (in the modern sense of internet intermediated crowdfunding) in 2011. In that year, academics at Griffith University worked with others to raise funds for 56 Inch Circus (McGuffin et al., 2011) and an academic at the University of New England was involved in a campaign to raise funds for Subak with Art Festival (Brooks et al., 2011). Since then, a small number of universities have encouraged staff to undertake crowdfunding as part of their academic role. The University of Western Australia, for example, clearly badges its crowdfunding campaigns with the university name (Personal communication, July 30, 2017). Deakin University has encouraged staff to undertake crowdfunding campaigns and provided a development program to assist them with their campaigns (D. Verhoeven, personal communication, March 4, 2016).

Universities occupy an interesting position in the crowdfunding space, as they have historically encouraged their academics to engage with the public as intellectuals as well as encouraging them to raise funds for their research. They are being encouraged by the government to demonstrate the public benefit or impact of their work (Brook, 2018; Chubb \& Reed, 2018; Chubb \& Watermeyer, 2016; Commonwealth of Australia, 2017; CSIRO, 2015; M. C. Evans \& Cvitanovic, 2018; M. M. Jones et al., 2013; Penfield et al., 2014). Crowdfunding allows academics to undertake all these activities at the same time - they can present their ideas to the public in an attempt to raise funds for their work.

The public nature of crowdfunding makes it an excellent option for research activities that produce public good, which can used by others without exclusion or depletion, such as open source research (T. Mann \& Blunden, 2010; Pomerantz \& Peek, 2016). Conversely, it is not a suitable funding mechanism for all research. It is not suitable for research that is commercially sensitive or where a commercial advantage may be lost by revealing ideas to the public, research that involves confidential intellectual property, may lead to a theoretical breakthrough or where there is the possibility of being beaten to a discovery by rival researchers, or research that attracts the attention of well-organized opposition groups, such as animal liberationists or anti-vaxxers. 
In undertaking a crowdfunding campaign, a series of contracts are formed between the parties, and several transactions take place. Figure 1 shows the relationships between the crowdfunders who are seeking funding, the crowdfunding service and the supporters who are contributing funds.

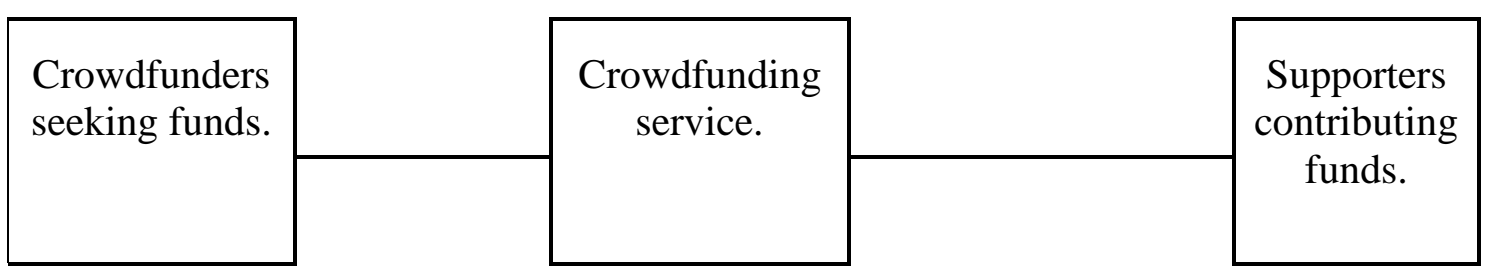

Figure 1: Simple model of crowdfunding

The crowdfunder and their supporters both form contracts with the crowdfunding service when they accept the terms and conditions of using the service. The significant moments in the relationships include:

- When the crowdfunding campaign is published.

- When a supporter makes a contribution.

- When the crowdfunding campaign closes.

- When the crowdfunding service releases funds to the crowdfunder.

- When the promised aim of the campaign is achieved, either by the creation of a public-good like research, or by the delivery of goods or services.

If the campaign is successful, a contract or trust is formed between the supporters and the crowdfunder. This contract comes to an end when the aim of the campaign is achieved. In addition to this, all parties will have contracts with payment services, either to pay funds to the campaign (supporters), receive funds for the campaign and pay funds to the crowdfunder (crowdfunding service) and to receive funds from the crowdfunding service (crowdfunder).

The different parties are governed by a mixture of legislation, contract law, and/or common law.

The model shown in Figure 1 becomes more complicated when the crowdfunders are employees of an organization, such as a university. Figure 2 shows the way that the relationship changes when the crowdfunders are undertaking their crowdfunding activities as employees of an organization, such as a university.

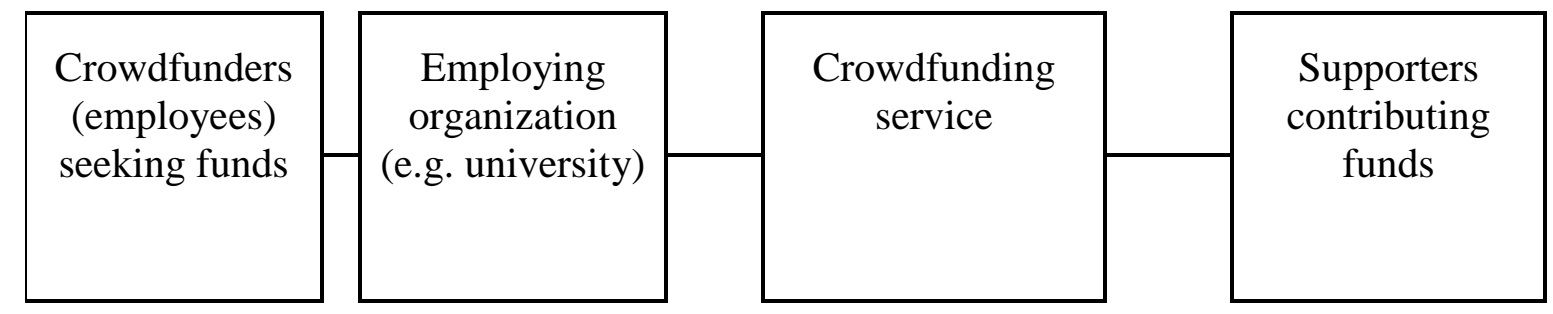

Figure 2: Model of crowdfunding for organisational employees 
In Figure 2, additional contracts include the employment contract between the crowdfunding academic and their university. If the campaign succeeds, funds are transferred to the university. In this case, it is unclear whether the university has a contract with the crowdfunding service. On the one hand, the academic is acting as an employee of the university. On the other hand, the terms and conditions of crowdfunding services are generally designed with individuals, not organizations, in mind. In addition, it is unclear whether the supporters realize that they are forming a contract with the university when the funds are transferred.

As well, universities introduces a range of organizational policies that govern the behaviour of staff members.

\section{RESEARCH METHODS}

This chapter draws on several data sets. The first is data obtained from twenty-three interviews with crowdfunding academics $(n=9)$, university administrators $(n=13)$ and crowdfunding service personnel $(n=1)$ conducted in 2016 and 2017. The second is a literature review of publications relating to Australian crowdfunding. The third data set are changes in the terms and conditions governing use of Kickstarter between December 2010 and July 2019 (O’Donnell, 2019).

\section{Interviews}

As part of a $\mathrm{PhD}$ project to understand how universities were supporting crowdfunding, 23 interviews with academics and administrative staff at three universities and one crowdfunding service were conducted. While most interviews were one on one (20 interviews), a small number involved two interviewees (three interviews). The academics interviewed included those that had conducted both successful and unsuccessful campaigns. As preparation for these interviews, a review of the public material related to their campaigns was undertaken, both on the crowdfunding platform and on social media. Academic interviewees were asked to tell the story of their campaigns, with the campaign page open in front of them for reference. If they had conducted multiple campaigns, they were asked to focus on their most recent campaigns. Administrators who were interviewed included senior university staff who were responsible for setting policy, as well as bureaucrats from research administration, finance and advancement (donor relations) responsible for supporting the campaigns. Interviews with administrators all started with the seed question of 'please describe a problem associated with crowdfunding', to try to avoid discussions based on organizational narratives of success. In both cases, interviews were semi-structured and were designed to last an hour.

Interviews were analyzed both through close reading and thematically using NVivo (Guest et al., 2006; Rowley, 2002, 2012). For this chapter, interviews were coded for comments that discussed risk (including synonyms and antonyms), and legal or general issues that had been identified from the literature.

The main issues that emerged from the analysis of the interviews related to non-performance of service and breach of contract, concerns about intellectual property, false pledges and crowdfunding systems, missing payments and payment systems, university policies, 
university concerns about reputational risk, stalking and harassment by the public, and motivation.

\section{Literature review}

The literature review encompassed research-related crowdfunding campaigns. Because crowdfunding for research is a relatively recent phenomena, this included both Australian and international campaigns. One example that illustrated the risks for universities was that of through the Glowing Plants: Natural Lighting with no Electricity campaign on Kickstarter (Callaway, 2013; A. Evans, n.d.; Franzen, 2013; Kickstarter, n.d.; Regalado, 2016). In 2013, independent synthetic biology researchers from the United States (US) raised US\$484,013 from 8,433 supporters through the Glowing Plants: Natural Lighting with no Electricity campaign. Most supporters chose rewards that would provide them with seeds to grow glowing plants. The campaign attracted a great deal of controversy. People were concerned about the risk of bioluminescent plants spreading in the wild, and cross-pollinating with other species (Dzieza, 2013). After five years of work, the glowing plants researchers reported that, despite their best efforts, they had failed. Even so, many supporters were very vocal in their disappointment at not receiving seeds to grow their own glowing plants (Brewster, 2017; Regalado, 2016).

The author also undertook an archival search of articles and news items related to legal breaches and other risks related to Australian donation and reward-based crowdfunding campaigns. This was a snowball sample for content analysis (Krippendorff, 2018) starting with known issues (e.g. news items relating to footballer Israel Folau and medical fraud on GoFundMe), and working outward to track down other campaigns mentioned in news articles and blog posts.

It also drew on two independent web sites have been established to identify fraudulent crowdfunding campaigns, Kickscammed (http://kickscammed.com/) for Kickstarter and GoFraudMe (http://gofraudme.com/) for GoFundMe, which collect examples of questionable crowdfunding campaigns. Both of these sites were searched for Australian examples, as well as for examples that related to research activities.

\section{Frameworks for Understanding Risk in Crowdfunding}

While there are many frameworks that address crowdfunding, the author could only find three that specifically addressed risk in crowdfunding. In 2015, Arenas et. al. drew on Sherer and Alter's (2004) work system risk framework to examine risks related to three equity crowdfunding platforms. The work system risk framework is designed to categorize risks in information systems operations and projects. It provides for 33 types of risk factors, grouped into nine categories. These categories include risks related to: work practices; participants; information; technologies; products and services; customers; environment; infrastructure; and strategies. Risk factors range from 'technology performance is inadequate' in the 'technologies' category to 'inadequate managers and leaders' in the 'participants' category (Sherer \& Alter, 2004). However, the work system risk framework is designed to help managers of information systems to understand and categories the large number of risks they face when they are managing, commissioning or developing information systems. Using this framework provides a techno-centric and managerial view of the risks involved. This has limited use when considering entrepreneurial activities related to financial transactions, such as crowdfunding. 
In 2017, Schwienbacher published a model of entrepreneurial risk-taking in crowdfunding campaigns. It used micro-economic assumptions to model all-or-nothing rewards-based crowdfunding (pre-purchase) that might attract investors and that involved ideas could be replicated or stolen. Within this scope, it discussed the risk of not achieving a crowdfunding target, of achieving the target but not having enough funds to produce the reward, and the risk of having intellectual property stolen. It discussed varying the target amount for the campaign as a way of compensating for these risks, as well as varying the amount of effort involved, and attracting investment at the end of the campaign (Schwienbacher, 2017). The scope of this model was too specific to be useful for this paper.

In 2017, Stack et al published a useful framework for evaluating legal risk in crowdfunding. Stack et al. (2017, para. 10) posits "...that in any crowdfunding platform there are both wellintentioned and ill-intentioned fund seekers and investors...”. Stack et al., (2017) used four examples of risks to illustrate the four different combinations of these four variables:

- Fraud: ill-intentioned entrepreneurs stealing the funds of well-intentioned investors.

- Intellectual property theft: ill-intentioned investors stealing the intellectual property of well-intentioned entrepreneurs.

- Money laundering: ill-intentioned investors working with ill-intentioned entrepreneurs.

- Failure by success: so many well-intentioned investors subscribing to the campaign of a well-intentioned entrepreneur that they cannot cope with the scale of the project

This was a useful framework as it combined the intention of the actor with their actions within the system. It provides a simple way to categorize most risks related to crowdfunding. The framework is designed for equity, lending and reward-based crowdfunding but it can also be applied to donation-based crowdfunding. However, it ignores the possibility of risks related to the crowdfunding service or other external factors.

\section{Analysis and Synthesis}

Each of the data sets were analyzed separately. This analysis was then combined through the application of Stack et. al's (2017) framework of ill-intentioned or well-intentioned actors. While this provided a useful understanding of the risks, it was found that some risks fell outside the framework. All risks (both those within the framework and those outside it) were grouped according to the coding used in analyzing the interviews.

Finally, the author has synthesized this discussion into a new framework for ameliorating risk in institutional crowdfunding. It provides suggestions on what organizations might consider doing before crowdfunding campaigns are developed, while crowdfunding campaigns are underway, and after crowdfunding campaigns are completed.

\section{ACADEMIC CROWDFUNDING CAMPAIGNS}

Research into academic crowdfunding has produced two distinct strands of literature; case studies of academics who have undertaking crowdfunding campaigns and detailed analysis of multiple campaigns. While crowdfunding generates much public data that lends itself to statistical analysis of large crowdfunding data sets, to date the author has not discovered any large-scale statistical analysis of research crowdfunding. 
Personal case studies published through refereed articles and blog posts have provided valuable information on emerging activity. These publications emphasize the significant investment of time and effort required to attract funds, that the majority of funds come from friends, family and colleagues, and that campaigns with all-or-nothing targets often need large contributions to be successful (R. English, 2014; Gill, 2014; Teytelman, 2015a; M. Thomson, 2014). They explain the lack of other avenues of funding which had encouraged them to try crowdfunding, and how crowdfunding, while worthwhile, did not replace traditional sources of funding, particularly government funding (R. English, 2014; Moore, 2013; Teytelman, 2015b).

In 2015, Hui and Gerber interviewed 27 US academics who had undertaken crowdfunding campaigns. They found that academics were motivated through a desire to share their work and a need for funds, and that they needed to use more accessible language to attract an audience. Many crowdfunding campaigners are reluctant to ask their personal networks (often friends, family and colleagues) for funding. Academics have described it as 'hounding' or being a 'glorified begger' (Gerber \& Hui, 2013; Hui \& Gerber, 2015).

Byrnes (2012), Faulkes (2014) and Wheat et al (2013) analyzed 182 projects undertaken over a 33 to 45 day period of all-or-nothing research crowdfunding campaigns. Their main finding was that researchers need to engage a broad audience to meet their targets. They recommended that academics build their audience before they begin their crowdfunding campaigns. They were able to show that academics had to attract 100 views of their campaign webpage to gain one contribution. If they did not already have a large audience, it was difficult for them to build a support base while also trying to reach a target in 4 to 6 weeks (Byrnes, 2012; Faulkes, 2012, 2014; Wheat et al., 2013).

In 2018, Ikkatai, McKay and Yokoyama surveyed 950 members of the public and 30 Japanese academics who had conducted crowdfunding campaigns. They found that, while the public thought that peer review of crowdfunding was important, the great majority of their academic respondents did not think that peer review was desirable before academics could launch crowdfunding campaigns (Ikkatai et al., 2018).

Verhoeven and Palmer provided analysis of the first eight campaigns undertaken by an Australian university, and then subsequent analysis that included nineteen campaigns with all-or-nothing targets. They described crowdfunding as a "flipped funding model" where researchers proposed minimal targets which were fully funded, rather than aspirational grant application budgets that funding bodies often only partially fund (Verhoeven \& Palmer, 2015, p. 6). They emphasized the value of research crowdfunding campaigns to develop the research communication and entrepreneurial skills of the participants, as well as providing their research with a visible presence in the community. They also touch on some of the organizational difficulties encountered when introducing a new funding model to a university (Verhoeven, Palmer, Seitzinger \& Randall, n.d.). They discuss “...the collection and visualization of social media (Twitter) data related to the research crowdfunding projects...” (S. Palmer \& Verhoeven, 2016, p. 291). Their analysis of the density and width of Twitter networks associated with eight research crowdfunding campaigns showed that research campaigns succeed more often when they move beyond tweets "by" researchers, to others tweeting "about” their campaigns. Success was achieved by “...not by sending lots of tweets per se, but by extending the sequence of retweets and other re-broadcasts about their project to new/unique potential pledgers” (S. Palmer \& Verhoeven, 2016, p. 297). 


\section{LAW APPLICABLE TO CROWDFUNDING}

The law that is relevant to the legal risks to universities in Australia when their academic staff engage in crowdfunding campaigns is quite complex as it depends on the nature of the crowdfunding campaign. However, in most cases, the funds provided through a crowdfunding campaign for academic research will be considered a donation.

For an Australian university to accept donations, it must be a registered charity, meeting the requirements set out in the Australian Charities and Not-for-profits Commission Act 2012 (Cth), as well as any relevant State or Territory-based legislation governing charitable donations.

The Law Council of Australia in its document Crowdfunding Guidance for Australian legal practitioners (2019) points out that donation-based crowdfunding is treated as making a gift and generally a gift does not constitute an enforceable contract unless the crowdfunder makes specific promises regarding the use of the gift. This is rarely the case in crowdfunding. This means that there are very few enforceable remedies in contract law related to gifts if a supporter is not happy with the use of their funds.

The Australian Consumer Law (ACL) in the Australian Competition and Consumer Act 2010 (Cth) does not apply to donation-based crowdfunding, as it applies to persons engaged in trade or commerce. The tort of deceit might apply to a misleading crowdfunding campaign if the academic made false representations knowing they were false, the funder relied on those representations and he or she suffered damage as a result (Law Council, 2019). Also, specific promises regarding the use of the gift may create a trust if the relevant agreement indicated that there was an intention to create such a trust.

With rewards-based crowdfunding that involves the promise of development or supply of products (either as the main purpose of the crowdfunding, or as small 'thank-you' rewards), s. 18 of the ACL may apply. It prohibits misleading and deceptive conduct in trade or commerce and offers protections against false or misleading representations about goods and services. This includes pre-purchase, as well as the provision of 'thank you' rewards in exchange for funds. As well, aggrieved supporters might also have remedies under contract law (Law Council of Australia, 2019; Matthew, 2019).

At this stage, crowdfunding does not fit well with the existing body of law. Vitale (2013, p. 310) argues that "the challenge regulators now face is to adapt the existing pre-crowdfunding framework to the post-crowdfunding world, so that the full benefits of the crowdfunding phenomenon may be enjoyed without compromising the overall regulatory outcome”.

In Australia, the only legislation that specifically relates to crowdfunding pertains to equitybased crowdfunding, which is not discussed in this chapter. The two relevant acts are the Corporations Amendment (Crowd-sourced Funding) Act 2017 (Cth) and the Corporations Amendment (Crowd-sourced Funding for Proprietary Companies) Act 2018 (Cth).

However, contract law does play an important part in governing the relationships between the funders, the crowdfunding services and the supporters. To set up a campaign, the crowdfunder must agree to be bound by the terms and conditions of the service. As mentioned earlier, most of the crowdfunding services activities are covered by jurisdictions other than Australia. As events occur and problems arise, the crowdfunding services update 
their terms and conditions. To illustrate this, the author tracked every change of the text of Kickstarter's guidelines, rules, prohibited items and terms and conditions between December 2010 and July 2019 (when the data was collected). This dataset has been published as open data (O’Donnell, 2019).

Crowdfunding services can limit or encourage activity through their terms and conditions. After synthetic biology researchers raised US\$484,013 through the Glowing Plants: Natural Lighting with no Electricity campaign, Kickstarter updated their prohibited items list to prohibit genetically modified organisms as rewards (Callaway, 2013; A. Evans, n.d.; Franzen, 2013; Kickstarter, n.d.; Regalado, 2016). This was a reversal of their Guidelines when they launched, which read "Kickstarter is full of imaginative applications of technology: ... open source DNA projects.... These projects are great!” (Kickstarter, 2010, para. 7).

In addressing the issue of whether rewards-based crowdfunding services are raising funds for research and development or are selling goods via pre-purchase. Kickstarter explicitly stated in 2012 that it was not a store (Strickler et al., 2012). That is, rewards-based crowdfunding campaigns are not a pre-purchase vehicle and are not engaged in the supply of goods to consumers. Others disagree, with (Ganatra, 2015, p. 1434) arguing that Kickstarter "functions as a platform for entrepreneurs that offer the very product in development as a "reward" either earlier than a formal release and/or at a discounted price”.

However, Kickstarter's position was supported in 2018 by a judge in the Central District Court of Israel, who expressed a preliminary position that (Neuman, 2018, para. 17): there is no promise on the part of the company to supply the finished product, but only a request for a financial donation that would help in its development - which sometimes succeeds, and sometimes does not.

In 2019, the US Federal Trade Commission seemed to also support Kickstarter's position when they commenced an action against Douglas Monahan, who ran multiple successful crowdfunding campaigns on Kickstarter and Indiegogo which raised US\$800,000 to develop the iBackPack, a technological backpack (Federal Trade Commission, 2019; Monahan, 2016b, 2016a). The Federal Trade Commission believed that only a small proportion of the funds raised were used to develop the iBackPack. They stated that "if you raise money by crowdfunding, you don't have to guarantee that your idea will work... But you do have to use the money to work on your idea” (Federal Trade Commission, 2019, para. 3).

In 2017, a Kickstarter patron with the user name 'Encik Farhan' was making large pledges and then disputing the charges with their credit card company after the reward had shipped (Heberling, 2013a, 2013b). After it was discovered that the user had done this to multiple (possibly hundreds) of projects, Kickstarter changed their policies to protect creators from this sort of theft (Heberling, 2018).

Payment systems also place restrictions on what can be done through crowdfunding through their own terms and conditions. While it was still under development, Kickstarter's guidelines read “projects must meet Amazon payments' acceptable use policy” (Kickstarter, 2010a, para. 4).

\section{Fraud, Misrepresentation and the Criminal Law cases}


There has been remarkably little research into legal risks related to donation or reward-based crowdfunding, aside from the examination of fraud in rewards-based crowdfunding. The research that has been done has mainly been focused on the US.

The wisdom of the crowd (Surowiecki, 2005) can sometimes help to detect fraudulent or misrepresentational claims in crowdfunding campaigns. However, this is not always the case. In 2016 Cumming et al identified 197 potentially fraudulent campaigns from Kickstarter, over the period from 2010 to 2015. They described a suspected fraudulent crowdfunding campaign as one where the rewards had been significantly delayed (by more than one year) and the campaign initiators cease communicating with their supporters for more than six months after an unmet delivery date. They also identified suspected fraud when the promised product or reward was never delivered and the supporters were not fully refunded. Of these 197 potentially fraudulent campaigns, 44 were detected and cancelled before the end of the campaign. The overwhelming majority (147 campaigns) were funded and only suspected of fraud when the promised product or reward was not delivered (Cumming et al., 2016).

There have been two prosecutions in Australia relating to donation-based crowdfunding to raise funds for cancer treatment costs. The first was in 2015 when Diakko Santaali raised A \$10,550 via GoFundMe, to assist with treatment costs for pancreatic cancer. In 2016 he pleaded guilty to one count of dishonestly obtaining a sum of money in the Brisbane Magistrates Court (Brennan, 2016; GoFraudMe, 2016). In the second case in 2018, Lucy Wieland raised almost $\mathrm{A} \$ 55,000$ via GoFundMe, to assist with treatment related to ovarian cancer. She was charged with fraud in the Brisbane Magistrates Court in the same year. Shortly after she was charged, GoFundMe Australia introduced changes to its terms and conditions to protect supporters (Hinchliffe, 2018; Rafferty, 2018).

Both of these cases were exposed due to the public nature of crowdfunding. Other than that, as the Law Council of Australia notes, "there is little published case law that addresses crowdfunding and generally only in passing” (Law Council of Australia, 2019, p. 17).

For universities, though, the possibility of misrepresentation about what a crowdfunding campaign will do remains a potential risk to reputation.

\section{DISCUSSION}

\section{Risks in University Crowdfunding in Australia}

Fifteen risks have been identified through the interviews and the archival research. Table 3 lists the risks, the data that the risk was sourced from, and the types of crowdfunding campaigns that these risks pertain to.

\begin{tabular}{|l|l|l|l|}
\hline Identified risks & Source of data & \multicolumn{2}{|l|}{ Type of campaign } \\
\hline Fraud & Stack et. al. and archives & Donations & Rewards \\
\hline Theft of intellectual property & Stack et. al. and interviews & N/A & Rewards \\
\hline Misrepresentation & Archives & N/A & Rewards \\
\hline Breach of contract & Interviews & Donations & Rewards \\
\hline Corruption & Stack et. al. and archives & Donations & Rewards \\
\hline Breach of terms & $\begin{array}{l}\text { Archives and Terms \& } \\
\text { Conditions }\end{array}$ & Donations & Rewards \\
\hline
\end{tabular}




\begin{tabular}{|l|l|l|l|}
\hline False pledges & Interviews and archives & Donations & Rewards \\
\hline Missing payments & Interviews & Donations & Rewards \\
\hline University policies & Interviews and archives & Donations & Rewards \\
\hline Conflict of interest & Archives & Donations & Rewards \\
\hline Missed opportunity & Interviews & Donations & Rewards \\
\hline Reputational risk & Interviews and archives & Donations & Rewards \\
\hline Stalking \& harassment & Interviews and archives & Donations & Rewards \\
\hline Social norms & Interviews and archives & Donations & Rewards \\
\hline Personal morality & Interviews & Donations & Rewards \\
\hline
\end{tabular}

Table 3: Summary of risks in university crowdfunding

These fifteen risks were categorized according to Stack et al's (2017) framework of crowdfunding risks.

\begin{tabular}{lc|c} 
& \multicolumn{1}{c}{ Fraud } \\
Well-intentioned & $\begin{array}{c}\text { Misrepresentation } \\
\text { Breach of contract }\end{array}$ & $\begin{array}{r}\text { Misrepresentation } \\
\text { Breach of contract } \\
\text { Missing payments }\end{array}$ \\
\cline { 2 - 3 } Ill-intentioned & Corruption & $\begin{array}{c}\text { IP theft } \\
\text { False pledges } \\
\text { Stalking \& harassment } \\
\end{array}$ \\
& Ill-intentioned & Well-intentioned
\end{tabular}

Academics

Figure 3: Crowdfunding risks according to the actions of the actors (Stack et al., 2017)

The framework accommodates seven of the identified risks:

1. Fraud: ill-intentioned academics stealing the funds of well-intentioned supporters.

2. Misrepresentation: ill-intentioned or well-intentioned academics leading wellintentioned supporters astray.

3. Non-performance of service (breach of contract): ill-intentioned or well-intentioned academics not fulfilling their contract with well-intentioned supporters.

4. Corruption: ill-intentioned academics working with ill-intentioned supporters.

5. Intellectual property theft: ill-intentioned supporters stealing the intellectual property of well-intentioned academics.

6. Stalking and harassment: ill-intentioned supporters targeting well-intentioned academics.

7. False pledges and missing payments. 
Stack et al's (2017) framework fails to accommodate the remaining nine identified risks

- Risks associated with the crowdfunding service who host the campaign or the payment services that facilitate the transactions.

$\circ$ Breach of terms and conditions: ill-intentioned or well-intentioned academics not heeding the terms and conditions of the crowdfunding service or payment service.

- Risks associated with the wider society that the campaign sits within.

$\circ$ Reputational risk: well-intentioned academics being criticized by members of the public.

- Risks associated with the organization that the academic sits within.

○ Missed opportunity: organizations (or parts of organizations) forgoing the rewards of crowdfunding by banning crowdfunding by academics, or by not rewarding it.

- Risks related to university policies.

$\circ$ Well-intentioned academics finding that crowdfunding is difficult because of the implementation of existing policies by well-intentioned university administrators.

- Risks associated with conflict of interest

○ Ill-intentioned or well-intentioned academics conducting campaigns where it is unclear whether they are acting as private individuals or as employees of the university.

- Risks related to social norms

- Well-intentioned academics finding that their expectations do not align with well-intentioned members of the public.

- Well-intentioned supporters being surprised when they are contacted by wellintentioned administrators asking for further donations to the university.

- Risks related to personal morality

$\circ$ Academics who find that crowdfunding does not align with their own personal morality or beliefs.

These nine identified risks do not necessarily fit neatly within the framework because the framework sees crowdfunding as a two-sided market, with crowdfunders on one side and their supporters on the other. However, crowdfunding is more complex than that. Additional participants include the crowdfunding service, the payment service used for transactions and, in the case of academic crowdfunding, the university. They do represent important risks to be considered by a university if academics undertakes a crowdfunding campaign for academic research.

\section{FRAMEWORK FOR MITIGATING AGAINST RISK}

The following framework builds on Stack et.al's (2017) framework but includes the other risks identified from the interviews and literature review. Universities, like other organizations, can provide a great deal of assistance to their staff when they are undertaking crowdfunding campaigns. Part of that support includes assisting them to understand and ameliorate the risks associated with public campaigns for funding. In doing so, they will also reduce their own organizational risks. 
These risks include legal risks related to fraud, misrepresentation, non-performance of service (breach of contract), as well as contractual issues relating to breach of terms and conditions. There are also issues that are best dealt with via organizational policies, such as corruption, reputational risks, public criticism and conflict of interest. There are also risks to staff such as public criticism, stalking and harassment.

Beyond that, there is the risk of missed opportunity, where universities discourage or do not allow their staff to undertake crowdfunding, and the risk that staff will be instructed to undertake crowdfunding against their better judgement or personal morality.

Organizations should consider how they might avoid, reduce or react to these risks before, during or after staff undertake crowdfunding campaigns.

Universities and other public organizations can mitigate most risks before crowdfunding campaigns are begun, and some risks after the campaign has ended. Since crowdfunding campaigns are relatively short (often four - six weeks), any mitigation strategies that take place during the campaign need to be clear and immediate. Table 4 provides a framework for dealing with the risks discussed in this chapter. It shows the mitigating actions that organizations such as universities can take before, during and after crowdfunding campaigns to ameliorate the risks discussed in this chapter of fraud; misrepresentation; non-performance of service (breach of contract); breach of terms and conditions; corruption; public criticism; conflict of interest; stalking and harassment; and missed opportunities due to 'no crowdfunding' rules and personal morality.

\begin{tabular}{|l|l|l|l|}
\hline & \multicolumn{2}{|l|}{ Mitigating actions before, during and after campaigns } \\
\hline Legal risks & Before & During & After \\
\hline Fraud & Review of proposals & Cancel the campaign & Public statement \\
\hline IP theft & Review of proposals & & $\begin{array}{l}\text { Enforceable policies; } \\
\text { public statement }\end{array}$ \\
\hline Misrepresentation & Review of proposals & Cancel the campaign & Assistance to deliver \\
\hline Breach of contract & $\begin{array}{l}\text { Review of proposals; } \\
\text { education of staff }\end{array}$ & Cancel the campaign & \\
\hline Corruption & $\begin{array}{l}\text { Whistle-blower } \\
\text { protection }\end{array}$ & Cancel the campaign & Enforceable policies \\
\hline False pledges & & Robust processes & Robust processes \\
\hline Missing payments & & & Robust processes \\
\hline
\end{tabular}




\begin{tabular}{|c|c|c|c|}
\hline $\begin{array}{l}\text { Risks related to } \\
\text { policies }\end{array}$ & Review of policies & & Review of policies \\
\hline Conflict of interest & \multicolumn{3}{|c|}{$\begin{array}{l}\text { Clear and enforceable policies on outside activity and conflict of } \\
\text { interest }\end{array}$} \\
\hline Missed opportunity & $\begin{array}{l}\text { Education of } \\
\text { managers }\end{array}$ & & $\begin{array}{l}\text { Promotion of } \\
\text { successful } \\
\text { campaigns }\end{array}$ \\
\hline Reputational risk & Education of staff & Support services & Public statement \\
\hline $\begin{array}{l}\text { Stalking \& } \\
\text { harassment }\end{array}$ & Education of staff & Support services & Support services \\
\hline Social norms & Education of staff & Support services & Support services \\
\hline Personal morality & Support services & Support services & Support services \\
\hline
\end{tabular}

Table 4: Framework for ameliorating risk in organizational crowdfunding

\section{Review of Proposals}

A review process will help to protect against campaigns that are fraudulent, misleading or deceptive or in breach of the terms and conditions of the crowdfunding site or the payment facilities. A review will also help to identify campaigns that might have difficulty actually delivering what they promise. The review should happen before campaigns are launched, or as soon as the organization knows of a current campaign.

Both Deakin University and the University of Western Australia reviewed their projects (D. Verhoeven, personal communication, March, 4, 2016; Western Australian University, personal communication, July, 30, 2017) The primary purpose of the review process was to forestall projects or campaigners that may not be successful. However, the review process also provided an organizational perspective and an opportunity to block any proposal that the university felt was not bona fide.

\section{Education of Staff}

Because crowdfunding is a relatively new way of funding research, there is a reasonable amount of misunderstanding and confusion about it. Education and training will assist staff to understand the risks and responsibilities inherent in research crowdfunding campaigns.

In particular, crowdfunding campaigns open organizations up to the risk of public criticism, both at the individual and the institutional level. Criticism might take the form of critical comments towards campaigners or sustained campaigns by organized groups (e.g. antivaxxers; climate deniers; animal protectionists). Knowing the risks before they start can help staff to decide if they want to undertake crowdfunding campaigns. 
Education can assist staff to understand the risks of harassment and stalking, as well as how to recognise it, what to do if they encounter it, and counselling and other remedies that are available if it happens.

Education could also be useful to help staff to understand what is expected of them in terms of successfully delivering what they have promised (non-performance of service).

Deakin University provided a peer-mentoring program, where staff that had already run successful crowdfunding campaigns were paired with staff that were undertaking campaigns for the first time (D. Verhoeven, personal communication, March, 4, 2016). While this was designed to assist staff to develop their campaigns, it also allowed experienced mentors to provide information about how to reduce risks and understand responsibilities.

\section{Promotion of Successful Campaigns}

One way to enthuse managers and staff regarding the possibilities of crowdfunding is to actively promote successful campaigns. This will help to demystify crowdfunding for those that are not familiar with it and encourage staff who may be interested in attempting a campaign. It will also send a clear signal that crowdfunding is an accepted practice at the university.

\section{Enforceable Policies}

Along with the education of staff, clear policies will help staff to understand their responsibilities, particularly around conflict of interest. Staff always have the option to run a campaign outside of their work. As public intellectuals, they can lend their support to campaigns being run by others. In this case, clear policies around outside activity and conflict of interest will assist staff to know when they should be acting as individuals, when they are acting as employees, and what the differences are between those two situations.

Clear policies can also help deal with misrepresentation, after the fact. Universities have procedures for dealing with issues related to research integrity. These policies and procedures can be used to deal with misrepresentation. Misconduct committees can determine whether staff were misguided or ill-intentioned when they misrepresented their research and recommend appropriate action.

These policies need to be enforceable. Where a staff member has egregiously breached university policies, they should be held accountable. There is an unfortunate tendency sometimes to take a lenient approach, backed by a non-disclosure clause, and allow offending staff to move institutions (or within an institution) with no discernible disadvantages (Oransky, 2018).

\section{Review of Policies}

Policies should be reviewed to ensure that they are fit for purpose. Policies that relate to issues such as stalking and harassment may have been developed in light of issues between students and staff. These may need to be revised to cope with stalking and harassment from members of the public. At regular intervals, policies can also be reviewed as new issues come to light. This is particularly important for a crowdfunding policy as it will be new and 
untested when first developed and may need to be reviewed and modified based on experience.

\section{Robust Processes}

Crowdfunding in universities requires robust processes to enact the policies. This is particularly true where accounting processes are concerned. Both academics and finance officers will need to understand what to do in the case of false pledges and missing payments. It should be clear who is responsible for following up on missing payments and what the processes are for doing so. Crowdfunding brings together a large number of relatively small contributions. Universities have robust processes for dealing with bad debtors, but may need to revise their processes to deal with a large number of relatively small missed payments.

\section{Whistle-blower Protection}

Some issues, such as corruption, are difficult to detect beforehand. Strong protective policies and procedures for whistle-blowers are probably the best way to encourage staff and students to come forward to report corrupt practices (Oransky, 2018).

\section{Education of Managers}

Because crowdfunding is an unconventional way to raise research funds, some managers may be opposed to it. This risks the university to losing the opportunity to gain the benefits (both monetary and intangible) that crowdfunding affords. Some discussion with, and education of, managers may be required before they will be willing to allow staff to undertake crowdfunding campaigns.

\section{Support Services}

In many instances, universities have programs in place to support staff for personal or professional reasons. Counselling services and legal advice should be available to staff if they are being publicly vilified, stalked or otherwise harassed. Staff should also feel supported if they choose not to undertake a campaign or undertake a campaign in a manner that fits within their personal ethical boundaries.

\section{Assistance to Deliver}

One of the simplest ways for an otherwise successful campaign to disappoint people is by failing to deliver what was promised. This may be despite the best efforts of the researchers, as was the case with the glowing plants campaign (Evans, n.d.). Disappointment might be as simple as an academic not sending out promised 'thank you' rewards, like coffee cups or teeshirts. Often it may be because campaigners have not kept in communication with their supporters after the campaign has ended, even though the academic promised to do so.

In all cases, universities can assist crowdfunding academics to deliver on what they have promised. Just as with other grants and contracts, successful crowdfunding campaigns should go through a post-award service that identifies what the implied contract is with the supporters of the campaign, a timeline for deliverables and how funds should be disbursed. University post-award systems are effective at tracking research funds and associated 
activities, and they can provide academics with prompts that can help to keep a project on track.

For reward-based campaigns like the glowing plants campaign, this can come through helping the academics to communicate with their supporters, and to explain why research takes a long time and entails the risks that it does.

Where there is a significant requirement for fulfillment services, it might entail providing assistance and advice through the university mail service or other areas of the university that have expertise in fulfillment services.

For almost all campaigns, assistance from the communications or advancement department can help academics understand how to effectively keep in touch with their supporters over an extended period of time.

\section{Cancel the Campaign}

Review processes will not always be able to identify proposals that are fraudulent or at risk of misrepresentation. Most review processes will be undertaken by administrators or academics who are not experts in the domain of the campaign leader. As such, fraudulent or misrepresentation proposals may not be obvious until they are made public and can be scrutinised by domain experts. Campaigns that are designed to foster corrupt practices will be deliberately hidden from university administrators. The university should have the power to take down (withdraw) fraudulent and corrupt campaigns immediately. They should also have the power to cancel campaigns that are shown to be in breach of the terms and conditions of the crowdfunding service or the associated payment service.

Projects that are at risk of misrepresentation are more difficult to assess. All research entails risk, and academics need to be given a chance to try new approaches. Peer review processes often favour orthodox approaches at the expense of unorthodox ideas. One of the advantages of crowdfunding is that it creates new experimental spaces. As such, if there is significant criticism from experts, the crowdfunder should be given the opportunity to review that criticism and decide whether to take down the campaign.

\section{Public Statement}

In many cases, after a campaign is finished (either because it has been cancelled or run its course), a clear public statement by the campaigner and the university will often help to reduce public criticism or misunderstanding. Where a campaign has been cancelled due to fraud, misrepresentation or breech of terms and conditions, a message that plainly states what went wrong, what remedial action was taken, and what steps have been taken to prevent it happening again will help to restore confidence.

Where there has been significant public criticism and controversy over a project, a clear statement of principles and support of staff will help to make it clear where the university stands and help staff to understand that their organization supports them.

\section{FURTHER RESEARCH DIRECTIONS}


This chapter sits within a PhD project to examine whether crowdfunding can be a sustainable research funding mechanism for Australian universities. The main contribution of this chapter is the framework for ameliorating risks before, during and after crowdfunding campaigns. As such, the main avenue for further research would be testing the robustness of the framework and to refine it. It would also be worthwhile seeking to apply the framework to organizations other than universities.

In addition to this, further research could be undertaken to extend Stack et. al's (2017) framework to include additional actors such as research services, payment services and the universities.

During the development of this chapter, the author undertook a close reading of the changes to the terms and conditions of the Kickstarter crowdfunding platform (O'Donnell, 2019). This data, while fascinating, has only been used to describe the change of rules relating to genemodification. Further analysis would be useful to understand how crowdfunding services have responded to emerging risks and undesirable behavior by modifying their terms and conditions.

\section{CONCLUSION}

Based on a literature review interviews with university academics and administrators, archival research and a close examination of the terms and conditions of a crowdfunding platform, this chapter has identified fifteen risks that could result from academics undertaking crowdfunding at Australian universities.

These risks were categorized according to the Stack et al (2017) framework for evaluating risks in crowdfunding campaigns. A significant number of risks were found to fall outside of the framework, as the framework assumed crowdfunding was a two-sided market involving only the crowdfunder and their supporters. Risks that fell outside of the framework included risks related to other participants, such as the university, the crowdfunding service and the payment services that facilitate the crowdfunding transactions.

A new framework was developed to categorize the suggested ways of responding to these risks. This framework provides solutions that can be implemented before crowdfunding campaigns begin, during crowdfunding campaigns and after crowdfunding campaigns are concluded. These solutions will not eliminate the risks entirely. Nor will they provide a complete solution when the risks result in harm to an individual or an organization. They will, however, help to ameliorate the risks of crowdfunding in Australian universities.

This framework is provided so that academics, administrators, supporters, universities, crowdfunding services and regulators have a better understanding of both the risks involved and ways to reduce the effect of these risks. Academics undertaking crowdfunding campaigns can use the framework to improve the planning of their campaigns. While Australian universities that are providing support to researchers can use this framework as a checklist to improve their support for crowdfunding of academic research. Australian universities that are considering developing policies around crowdfunding can also use this framework to understand these risks and guard against them.

\section{REFERENCES}


Arenas, A., Goh, J. M., \& Podar, M. (2015). A work-systems approach to classifying risks in crowdfunding platforms: An exploratory analysis. In Twenty-First Americas Conference on Information Systems (AMCIS 2015) Proceedings. Fajardo, Puerto Rico: US Association for Information Systems.

Belleflamme, P., Lambert, T., \& Schwienbacher, A. (2013). Crowdfunding: Tapping the right crowd. Journal of Business Venturing, 29(5), 585-609. doi:

https://doi.org/10.2139/ssrn.1578175

Brennan, R. (2016, June 13). Sick truth behind this bloke’s GoFundMe appeal. Courier-Mail. Retrieved from https://www.couriermail.com.au/news/queensland/crime-andjustice/brisbane-man-diakko-santaali-guilty-of-fraud-after-gofundme-page-appeal/newsstory/6fe077e6e3d6ec33b4f2b78442c57b0b

Brewster, S. (2017, April 19). Inside the glowing-plant startup that just gave up its quest. Wired. Retrieved from https://www.wired.com/story/inside-the-glowing-plant-startup-thatjust-gave-up-its-quest/

Brook, L. (2018). Evidencing impact from art research: Analysis of impact case studies from the REF 2014. The Journal of Arts Management, Law, and Society, 48(1), 57-69. doi: https://doi.org/10.1080/10632921.2017.1386148

Brooks, M., McMillan, C., \& Surya Darma, I. G. M. (2011, December 13). Subak with art festival. Pozible [Crowdfunding platform]. Retrieved from https://pozible.com/project/4080

Byrnes, J. E. K. (2012, December 15). SciFund in 3 Rounds. \#SciFund Challenge. Retrieved from https://scifundchallenge.org/2012/12/15/scifund-in-3-rounds/

Callaway, E. (2013). Glowing plants spark debate. Nature News, 498(7452), 15. doi: https://doi.org/10.1038/498015a

Chubb, J., \& Reed, M. S. (2018). The politics of research impact: Academic perceptions of the implications for research funding, motivation and quality. British Politics, 13(3), 295311. doi: https://doi.org/10.1057/s41293-018-0077-9

Chubb, J., \& Watermeyer, R. (2016). Artifice or integrity in the marketization of research impact? Investigating the moral economy of (pathways to) impact statements within research funding proposals in the UK and Australia. Studies in Higher Education, 42(12), 2360-2372. doi: https://doi.org/10.1080/03075079.2016.1144182

Australian Charities and Not-for-profits Commission Act (2012) (Cth).

Commonwealth of Australia. (2017). Assessing the engagement and impact of university research. National Innovation and Science Agenda. Retrieved from https://www.innovation.gov.au/page/measuring-impact-and-engagement-university-research

Corporations Amendment (Crowd-sourced Funding) Act (2017) (Cth).

Corporations Amendment (Crowd-sourced Funding for Proprietary Companies) Act (2018) (Cth). 
CSIRO. (2015). Impact evaluation guide. Retrieved from https://www.csiro.au/impact

Cui, Y., \& Zeng, C. (2016). Regulation of Equity Crowdfunding in China. DEStech

Transactions on Economics, Business and Management. doi:

https://doi.org/10.12783/dtem/icem2016/4035

Cumming, D. J., Hornuf, L., Karami, M., \& Schweizer, D. (2016). Disentangling

crowdfunding from fraudfunding. Munich, Germany: Max Planck Institute for Innovation \&

Competition. Retrieved from http://hdl.handle.net/11858/00-001M-0000-002A-E932-7

Cumming, D. J., Leboeuf, G., \& Schwienbacher, A. (2015). Crowdfunding models: Keep-ItAll vs. All-Or-Nothing. Social Science Research Network. Retrieved from http://papers.ssrn.com/abstract=2447567

Department of Education and Training. (2017). 2018 Higher Education Research Data Collection: Specifications for the collection of 2017 data. Retrieved from https://docs.education.gov.au/node/44986

Dzieza, J. (2013, August 18). Plants that glow in the dark spark heated debate. Retrieved from https://www.thedailybeast.com/articles/2013/08/18/plants-that-glow-in-the-dark-sparkheated-debate

English, R. (2014). Rent-a-crowd? Crowdfunding academic research. First Monday, 19(1). doi: https://doi.org/10.5210/fm.v19i1.4818

Evans, A. (n.d.). Glowing plants: Natural lighting with no electricity [Crowdfunding campaign]. Kickstarter. Retrieved from

https://www.kickstarter.com/projects/antonyevans/glowing-plants-natural-lighting-with-noelectricity

Evans, M. C., \& Cvitanovic, C. (2018). An introduction to achieving policy impact for early career researchers. Palgrave Communications, 4(1), 88. doi: https://doi.org/10.1057/s41599018-0144-2

Faulkes, Z. (2012, December 15). SciFund in 3 rounds, part 2: Box plot fever. \#SciFund Challenge. Retrieved from https://scifundchallenge.org/2012/12/15/scifund-in-3-rounds-part2-box-plot-fever/

Faulkes, Z. (2014, March 18). \#SciFund round 4 analysis. \#SciFund Challenge. Rettrived from https://scifundchallenge.org/2014/03/18/scifund-round-4-analysis/

Federal Trade Commission. (2019, May 6). FTC charges operator of crowdfunding scheme. Federal Trade Commission. Retrieved from https://www.ftc.gov/news-events/pressreleases/2019/05/ftc-charges-operator-crowdfunding-scheme

Franzen, C. (2013, August 7). Kickstarter says it consulted scientists before banning genetically-modified organisms. The Verge. Retrieved from https://www.theverge.com/2013/8/7/4595876/kickstarter-founder-yancey-strickler-explainsban-GMOs 
Ganatra, J. H. (2015). When a Kickstarter stops: Exploring failures and regulatory frameworks for the rewards-based crowdfunding industry. Rutgers University Law Review, $68,1425-1472$.

Gerber, E. M., \& Hui, J. (2013). Crowdfunding: Motivations and Deterrents for Participation, ACM Transactions on Computer Human Interaction, 20(6), 34:1-34:32. doi: https://doi.org/10.1145/2530540

Gill, J. (2014, December 3). Crowd-funded science: Thoughts after 185 people gave us $\$ 10,733$ for research. The Contemplative Mammoth. Retrieved from https://contemplativemammoth.com/2014/12/03/crowd-funded-science-thoughts-after-185people-gave-us-10733-for-research/

GoFraudMe. (2016, June 13). Australian man pleads guilty to gofundme fraud, insists he really does have cancer. GoFraudMe. Retrieved from http://gofraudme.com/australian-manpleads-guilty-gofundme-fraud-insists-really-cancer/

Guest, G., Bunce, A., \& Johnson, L. (2006). How many interviews are enough?: An experiment with data saturation and variability. Field Methods, 18(1), 59-82.

https://doi.org/10.1177/1525822X05279903

Harms, M. (2007). What drives motivation to participate financially in a crowdfunding Community? [Masters Thesis, Vrije Universitaet Amsterdam]. Retrieved from http://www.ssrn.com/abstract=2269242

Heberling, A. (2013a, November 7). I feel like it's safe to discuss this publicly now. Alexheberling. Retrieved from https://alexheberling.tumblr.com/post/66288651102

Heberling, A. (2013b, November 8). Report: Kickstarter scammer 'Encik Farhan'-updated - the beat. Alexheberling. Retrieved from https://alexheberling.tumblr.com/post/66385162129

Heberling, A. (2018, May 19). We'll help resolve payment-card disputes. Alexheberling. Retrieved from https://alexheberling.tumblr.com/post/174069323037

Hinchliffe, J. (2018, October 25). GoFundMe changes policy to protect donors from sham causes. ABC News. Retrieved from https://www.abc.net.au/news/2018-10-25/gofundmepolicy-changes-protect-donors-from-shams/10428180

Hornuf, L., \& Schwienbacher, A. (2017). Should securities regulation promote equity crowdfunding? Small Business Economics, 49(3), 579-593. Doi.

https://doi.org/10.1007/s11187-017-9839-9

Hui, J. S., \& Gerber, E. M. (2015). Crowdfunding science: Sharing Research with an extended audience. In Proceedings of the 18th ACM Conference on Computer Supported Cooperative Work \& Social Computing. New York, NY: Association for Computing Machinery. 
Ikkatai, Y., McKay, E., \& Yokoyama, H. M. (2018). Science created by crowds: A case study of science crowdfunding in Japan. Journal of Science Communication, 17(3), A06. doi: https://doi.org/10.22323/2.17030206

Jones, M. M., Castle-Clarke, S., Manville, C., Gunashekar, S., \& Grant, J. (2013). Assessing research impact: An international review of the excellence in innovation for Australia trial [Commissioned research]. Santa Monica, CA: RAND Corporation.

Kappel, T. (2009). Ex ante crowdfunding and the recording industry: A model for the U.S. Loyola of Los Angeles Entertainment Law Review, 29(3), 375-385.

Kickstarter. (n.d.). Prohibited items. Kickstarter. Retrieved from https://www.kickstarter.com/rules/prohibited

Kickstarter. (2010, December 3). Community guidelines. Retrieved from https://web.archive.org/web/20101203214618/http://www.kickstarter.com/help/guidelines

Krippendorff, K. (2018). Content analysis: An introduction to its methodology. Thousand Oaks, CA: Sage Publications.

Law Council of Australia. (2019). Crowdfunding: Guidance for Australian legal practitioners. Retrieved from https://www.lawcouncil.asn.au/policy-agenda/regulation-ofthe-profession-and-ethics/crowdfunding-guidance-for-australian-legal-practitioners

Mann, T., \& Blunden, A. (Eds.) (2010). Australian law dictionary. 1st ed. Oxford, England: Oxford University Press.

Matthew, A. F. (2019). The conceptual legitimacy of support for risk-taking, entrepreneurship and innovation in Australian corporate law: A theoretical examination [PhD, Queensland University of Technology]. doi: https://doi.org/10.5204/thesis.eprints.132567

McGuffin, C., Wilks, N., Tomlinson, V., Anderson, B., \& Griswold, E. (2011, October 11). 56 inch circus [Crowdfunding campaign]. Pozible. Retrieved from http://www.pozible.com/project/1141

Monahan, D. (2016a). Ibackpack 2.0—4g mifi, hitech batteries—smart cables [Crowdfunding campaign]. Kickstarter. Retrieved from https://www.kickstarter.com/projects/ibackpack/ibackpack-20-3g-4g-mi-fi-bulletproofbluetooth-aud

Monahan, D. (2016b). Ibackpack—wifi, ultra-thin \& powerful batteries [Crowdfunding campaign]. Indiegogo. Retrieved from https://www.indiegogo.com/projects/1395593

Moore, C. (2013, June 8). Was it really only 30 days? Cryptocommonicon. Retrieved from https://cryptocommonicon.wordpress.com/2013/06/08/was-it-really-only-30-days/

Neuman, E. (2018, September 20). First class action filed in the world of crowdfunding (The Marker). Hamburger Evron \& Co. Retrieved from http://www.evronlaw.com/en/first-classaction-filed-world-crowdfunding-marker/ 
O’Donnell, J. (2019). Kickstarter rule changes over time [Data set]. Figshare. doi: https://doi.org/10.6084/m9.figshare.8942738

Oransky, A. I. (2018, July 30). How institutions gaslight whistleblowers-And what can be done. Retraction Watch. Retrieved from https://retractionwatch.com/2018/07/30/howinstitutions-gaslight-whistleblowers-and-what-can-be-done/

Palmer, S., \& Verhoeven, D. (2016). Crowdfunding Academic Researchers: The Importance of Academic Social Media Profiles. In C. Bernadas \& D. Minchella (Eds.), ECSM2016Proceedings of the 3rd European Conference on Social Media (pp. 291-299). Sonning Common, England: Academic Conferences and Publishing International Limited.

Penfield, T., Baker, M. J., Scoble, R., \& Wykes, M. C. (2014). Assessment, evaluations, and definitions of research impact: A review. Research Evaluation, 23(1), 21-32. doi: https://doi.org/10.1093/reseval/rvt021

Pomerantz, J., \& Peek, R. (2016). Fifty shades of open. First Monday, 21(5). doi: https://doi.org/10.5210/fm.v21i5.6360

Rafferty, S. (2018, October 18). Woman 'faked' ovarian cancer to collect $\$ 55 \mathrm{k}$ in donations, court told. ABC News. Retrieved from https://www.abc.net.au/news/2018-10-18/lu-wielandaccused-of-faking-stage-five-ovarian-cancer/10391034

Regalado, A. (2016, July 15). Why the promise of a plant that glows has left backers in the dark. MIT Technology Review. Retrieved from

https://www.technologyreview.com/s/601884/why-kickstarters-glowing-plant-left-backersin-the-dark/

Rowley, J. (2002). Using case studies in research. Management Research News, 25(1), 1627. doi: https://doi.org/10.1108/01409170210782990

Rowley, J. (2012). Conducting research interviews. Management Research Review, 35(3/4), 260-271. doi: https://doi.org/10.1108/01409171211210154

Schwienbacher, A. (2017). Entrepreneurial risk-taking in crowdfunding campaigns. Small Business Economics, 51(4), 843-859. doi: https://doi.org/10.1007/s11187-017-9965-4

Sherer, S. A., \& Alter, S. (2004). Information systems risks and risk factors: Are they mostly about information systems?. Communications of the Association for Information Systems, 14(1). doi: https://doi.org/10.17705/1CAIS.01402

Stack, P., Feller, J., O’Reilly, P., Gleasure, R., Li, S., \& Cristoforo, J. (2017). Managing risk in business centric crowdfunding platforms. In Proceedings of the 13th International Symposium on Open Collaboration, Galway, Ireland: Association for Computing Machinery.

Strickler, Y., Chen, P., \& Adler, C. (2012, September 21). Kickstarter is not a store.

Kickstarter Blog. Retrieved from https://www.kickstarter.com/blog/kickstarter-is-not-a-store

Surowiecki, J. (2005). The wisdom of crowds: Why the many are smarter than the few 
(reprint ed.). New York, NY: Anchor.

Swords, J. (2018). Interpenetration and intermediation of crowd-patronage platforms. Information, Communication \& Society. doi: https://doi.org/10.10

Teytelman, L. (2015a, March 24). Calibrating crowdfunding expectations. Yes, Another Science Blog. Retrieved from http://anothersb.blogspot.com.au/2015/03/calibratingcrowdfunding-expectations.html

Teytelman, L. (2015b, March 30). Biomedical funding is broken; crowdfunding is not the fix. Yes, Another Science Blog. Retrieved from http://anothersb.blogspot.com.au/2015/03/biomedical-funding-is-broken.html

Thomson, M. (2014, May 18). Unto the valley of death...of crowd funding science. $\mathrm{Dr} \mathrm{Mel}$ Thomson. Retrieved from https://drmelthomson.wordpress.com/2014/05/18/unto-the-valleyof-death-of-crowd-funding-science/

Verhoeven, D., Palmer, S., Seitzinger, J., \& Randall, M. (n.d.). Research my world: Crowdfunding research pilot project evalutation. Retrieved from http://www.deakin.edu.au/research/documents/research-my-world.pdf

Vitale, M. (2013). Crowdfunding: Recent international developments and its compatibility with Australia's existing regulatory framework. Journal of Banking and Finance Law and Practice, 24(4), 300-310.

Wheat, R. E., Wang, Y., Byrnes, J. E., \& Ranganathan, J. (2013). Raising money for scientific research through crowdfunding. Trends in Ecology \& Evolution, 28(2), 71-72. doi: https://doi.org/10.1016/j.tree.2012.11.001

\section{ADDITIONAL READING}

Budge, K. Lemon, N, \& McPherson, M. (2016). Academics who tweet: “Messy” identities in academia. Journal of Applied Research in Higher Education, 8(2), 210-221. doi: https://doi.org/10.1108/JARHE-11-2014-0114

Byrnes, J. E. K., Ranganathan, J., Walker, B. L. E., \& Faulkes, Z. (2014). To crowdfund research, scientists must build an audience for their work. PLOS ONE, 9(12). doi: https://doi.org/10.1371/journal.pone.0110329

Ferlie, E., Fitzgerald, L., Wood, M., \& Hawkins, C. (2005). The Nonspread of innovations: The mediating role of professionals. Academy of Management Journal, 48(1), 117-134. doi: https://doi.org/10.5465/AMJ.2005.15993150

Kolenda, N. (2016). The psychology of crowdfunding. Retrieved from https://www.nickkolenda.com/pdf/crowdfunding-psychology.pdf

Lemon, N., McPherson, M., \& Budge, K. (2015). Academics doing it differently: Wooing, hooking up and spinning stories. Journal of Perspectives in Applied Academic Practice, 3(2). doi: https://doi.org/10.14297/jpaap.v3i2.129 
McPherson, M., Budge, K., \& Lemon, N. (2015). New practices in doing academic development: Twitter as an informal learning space. International Journal for Academic Development, 20(2), 126-136. doi: https://doi.org/10.1080/1360144X.2015.1029485

Munro-Smith, N., \& Downs, J. (2011). Managing change in conservative institutions: Implementing and sustaining innovative educational design in university level courses. The International Journal of Learning, 17(11), 141-151.

Palmer, A. (2014). The art of asking: Or, how I learned to stop worrying and let people help. Retrieved from http://amandapalmer.net/theartofasking/

Palmer, S., \& Verhoeven, D. (2016). Crowdfunding academic researchers: The importance of academic social media profiles. In ECSM2016-Proceedings of the 3rd European Conference on Social Media. Caen, France: Academic Conferences and Publishing International Limited.

Verhoeven, D., \& Palmer, S. (2015). Because it takes a village to fund the answers: Crowdfunding university research. In L. Bennett, B. Chin, \& B. Jones (Eds.), Crowdfunding the future - media industries, ethics, and digital society (pp. 133-156). New York, NY: Peter Lang Publishing Inc.

\section{KEY TERMS AND DEFINITIONS}

Breach of contract: Failure to perform a contract, either in whole or in part (Mann \& Blunden, 2010)

Breach of duty of care: Failure to avoid or alleviate harm to others. The level of care required is measure by the standard of care (Mann \& Blunden, 2010)

Crowdfunder: Person or group of people who conduct a crowdfunding campaign to raise funds.

Crowdfunding: Raising funds from a group of people for a project or cause, typically using the internet (Harms, 2007; Kappel, 2009).

Crowdfunding Campaign: The period when a crowdfunder is actively seeking funding.

Crowdfunding Service: Organisations that facilitate crowdfunding via the internet. Their websites are often referred to as Crowdfunding Platforms.

Fraud: Dishonestly gaining advantage (Mann \& Blunden, 2010)

Misrepresentation: Falsehoods that induce someone to enter into a contract.

Misrepresentation may be fraudulent when it is intentional, innocent when it is unintentional and negligent when it is unintentional but there is a duty of care (Mann \& Blunden, 2010).

Morality: Prescriptions regarding right and wrong behaviour (Mann \& Blunden, 2010).

Performance: Satisfactorily completing the terms of a contract. By inference, nonperformance is not satisfactorily completing the terms (Mann \& Blunden, 2010) 
Public Good: Things that are available to all (nobody can be excluded) and cannot be used up (use by one does not reduce the use of another) (Mann \& Blunden, 2010).

Risk: The measure of the chance of harm occurring (Mann \& Blunden, 2010).

Social Norms: Cultural expectations governing the behaviour of people (Mann \& Blunden, 2010).

Standard of care: The benchmark for a person to avoid or alleviate the risk of harming others (Mann \& Blunden, 2010).

Supporters: People who provide funds to a crowdfunding campaign. Also referred to as Backers. Supporters who receive a tax deduction for their contribution may be called Donors. 